\title{
Biological Suppression of Stored Grain Insect Pests
}

\section{Deb $S^{*}$}

Department of Entomology, S. D. Agricultural University, India

Mini Review

Volume 2 Issue 2

Received Date: April 12, 2019

Published Date: April 30, 2019

DOI: $10.23880 /$ izab-16000146

University, C.P. College of Agriculture, Sardarkrushi nagar, Gujarat 388 110, India,

Tel: 917046107962; Email: debsushma@gmail.com

\section{Mini Review}

Stored products include all durable agricultural commodities which can be dried and stored in bulk. Due to un-controlled environmental conditions and poor warehousing technology, stored grain infestation is a very serious problem as various life stages of insects cause economic damage and deteriorates the quality of food grains and products. There are number of stored grain insect pests that infest food grains in farmer's go downs and public warehouses. More than 70 insect pests have been identified which attack stored grains and cereal products in store houses. The overall damage caused by these insect pests worldwide is estimated to be $10-40 \%$ annually [1]. Therefore, there is an urgent need to suppress the insect pest population of stored grain/products in order to maintain stored quality and its proper management.

Insecticidal use is a widespread practice for controlling pests of stored products. However, the ever increasing problems of insecticide resistance in stored grain insects, relatively limited number of insecticides available for stored product protection and the increasing environmental and health concerns surrounding insecticidal use have sparked renewed interest in the ecofriendly approaches to control insect pests of stored products. Therefore, non-chemical methods with special reference to biological control including behavioral, botanical and microbial control can be practiced solely or in combination as effective alternative of chemical control. Few natural products such as volatile oils and their constituents can also be used to control stored grain insects. Further, volatile repellents after evaporation in the medium deter insects from feeding and cause high mortality rate in insects.

\section{Behavioral Control}

Pheromones are used in behavioral control of insects either by applying male specific or female specific pheromonal substances. These are used for surveillance and detection of an infestation in stored grains. These are used to uphold communication disruption or mass trapping of insects by lures and attract. The primary component of the khapra beetle, Trogoderma granarium pheromone, 14- methyl-8-hexadecenal is now used to capture and kill large numbers of T. granarium. Wheat germ oil combined with sex pheromone is also used to attract and trap Trogoderma larvae. Lesser grain borer, Rhyzopertha dominica produces an aggregation pheromone that attracts both sexes. Synthesized pheromones are used in baited traps which were found effective in monitoring populations. Pheromones of other grain-infesting beetles and weevils are also identified and are used for trapping Tribolium spp., Sitophilus spp., Stegobium paniceum and Lasioderma serricorne in ware houses [1].

\section{Biological Control}

\section{Parasitoids}

Release of larval parasitoid, Bracon hebetor could cause 93.4\% mortality in Corcyra Cephalonica larvae [2] and activity of $B$. hebetor in Corcyra rearing room was observed throughout the year, except during April in Gujarat [3]. Combine release of egg parasitoid, Trichogramma pretiosum and larval parasitoid, B. hebetor found effective in suppressing Indian meal moth (84\%) and almond moth (98\%) population, while B. hebetor alone had suppressed almond moth population by $97.3 \%$ 


\section{International Journal of Zoology and Animal Biology}

[4]. T. pretiosum and T. carverae were found to be most suitable bio-agents against fig moth, Ephestia cautella and E. kuehniella [5]. Laboratory studies have shown the potential of solitary ectoparasitoid, Anisopteromalus calandrae in suppressing populations of maize weevil, Sitophilus zeamais in corn [6]; rice weevil, $S$. oryzae in wheat [7]; $R$. dominica in stored wheat [8]; pulse beetle, Callosobruchus chinensis [9] and C. maculatus [10]. Some other parasitoid found parasitizing and controlling stored grain insect pests are solitary ectoparasitoid, Choetospila elegans on S. zeamais in corn; larval-pupal ectoparasitoid, Dinarmus basalis on C. chinensis.

\section{Predators}

Anthocorid bug, Xylocoris flavipes is a cosmopolitan predator of different prey (pests) of stored commodities namely Tribolium casteneum, T. confusum, Crytolestes pusillus, R. dominica and T. granarium and one of the most studied candidates of biological control agent among the predatory bugs [11]. Dorylus labiatus is a most efficient predatory ant species on larvae and pupae of $C$. chinensis in stored chickpea with 84.64 and $98.26 \%$ mortality, respectively. Monomorium minimum, another predatory ant was found to be the most efficient egg predating species with $84.85 \%$ egg mortality [12]. According to Rahman, et al. [13], X. flavipes killed small and large larvae of $C$. pusillus than those of T. confusum and T. castaneum in the jar filled with wheat kernel and host. Females were reported to be more predaceous than those of males. Inoculative release of $X$. flavipes and Blaptostethus pallescens @30 nymphs/10kg of rice released separately had reduced significantly the emergence of $C$. cephalonica moth [14].

\section{Botanical Control}

Plant extracts, essential oils have shown insecticidal activity against field crop pests and household insect pests. Many of these oils have also shown high oviposition and growth inhibitory activity. The neem oil and kernel powder gave effective grain protection against stored grain insect pests like S. oryzae, T. castaneum, $R$. dominica, and $C$. chinensis at the rate of 1 to $2 \%$ kernel powder or oil [15]. Coconut oil has been found effective against $C$. chinensis, for a storage period of six months, when applied to green gram at 1\% [16]. The powders of Rauvolfia serpentina, Acorus calamus, and Mesua ferrea are used as a grain protectant against $R$. dominica [17]. Similarly, volatile compound diallyl disulphid isolated from neem have shown potent toxic, fumigant and feeding deterrent activity against stored grain pests, $S$. oryzae and $T$. castaneum [18]. Methyl salycylate from Securidacalonga pedunculata exhibited repellent and toxic properties against $S$. zeamais and $R$. dominica [19]. The herbal pallets made from neem seed (Azadirachta indica) Powder, Sitafal (Annona swuamosa) seed powder, asafoetida (Serula foetida), chilli powder and eucalyptus oil showed significant insecticidal activity against Bruchus chinensis [20]. Treatment with Carissa schimperi 5\% and Tagitus minuta $5 \%$ was effective against $S$. zeamais and can solve poor resources farmers' problems by integrating them with other control measures [21].

\section{Microbial Control}

\section{Fungi}

Conidia of Metarhizium anisopliae in stored wheat along with dust carriers has given significantly higher adult mortality of $T$. castaneum and less grain infestation [22]. Samodra, et al. [23] reported that Beauveria bassiana formulated in kaolin showed the highest mortality of $S$. oryzae and lowest grain weight loss in stored rice followed by talc and tapioca flour. According to Dhuyo, et al. [24], first and second instar larvae of larger grain borer, Prostephanus truncates were more susceptible to $B$. bassiana in stored maize than the third instar while pupal stage was found to be significantly more susceptible than other stages.

\section{Bacteria}

McGaughey, et al. [25] noticed good control (92\%) of Plodia interpunctella and E. cautella in bulk wheat and corn by treating the surface layers with dust or aqueous suspension of Bacillus thuringiensis. Ahmedani, et al. [26] evaluated three commercial formulations of $B$. thurinsiensis against T. castaneum and reported Ecotech Pro as more effective than Dipel ES and Bactospeine in suppressing the pest.

\section{Viruses}

A nuclear polyhedrosis and a granulosis virus have been isolated from E. cautella. Both the viruses infect $P$. interpunctella, whereas granulosis virus from $P$. interpunctella does not cross-infect E. cautella [27]. Another nuclear polyhedrosis virus has been isolated from C. cephalonica [28]; but it is not known whether it will cross-infect other moths or not. In all cases the young larvae were found most susceptible.

\section{Nematodes}

Strain Hawaii of Steinernema feltiae and strain USA/SC were found most virulent against T. confusum and $E$. 
kuehniella larvae, respectively [29]. The efficacy of three strains of $S$. feltiae against $S$. oryzae at five different concentrations and four different temperatures was tested by Laznik, et al. [30]. They found all the strains as most effective at $25{ }^{\circ} \mathrm{C}$ and highest concentration of nematode.

Entomopathogens viz., fungi, bacteria, virus and nematodes have an important place in the biological control because they have a wide host range, are harmless to the environment and human, and could be applied with conventional sprayers. They can be used more against stored product pests with the development of new biotechnical methods such as collecting pests in some stations to meet them with entomopathogens [31].

\section{Conclusion}

Biological control is an ecofriendly approach and can be easily followed without any risk. Use of pheromones, botanicals and biocontrol agents viz., $X$. flavipes, $A$. calandrae and B. bassiana have been found to effectively suppress some of the storage insect pests. Biological control of stored grain pests may prove effective, if used in appropriate manner, time and space. However, for biological methods to reach their full potential, an increased research effort is required.

\section{References}

1. Upadhyay RK, Ahmad S (2011) Management strategies for control of stored grain insect pests in farmer stores and public warehouses. World J Agril Sci 7(5): 527-549.

2. Patel RC, Yadav DN, Saramma PU (1982) Effectiveness of Bracon hebetor against Corcyra cephalonica infestation in go down. GAU Res J 7(2): 121-123.

3. Dabhi MR (2010) A Ph. D. thesis submitted to Anand Agricultural University, Anand, pp: 94.

4. Phillips $T$ (2000) Agriculture Research Service, Biological Research Unit, Kansas City- ARS News Service.

5. Steidle JL, Rees D, Wright EJ (2001) Assessment of Australian Trichogramma species (Hymenoptera: Trichogrammatidae) as control agents of stored product moths. J Stored Prod Res 37(3): 263-275.
6. Arbogast RT, Mullen MA (1990) Interaction of Maize Weevil (Coleoptera: Curculionidae) and Parasitoid Anisopteromalus calandrae (Hymenoptera: Pteromalidae) in a Small Bulk of Stored Corn. J Econ Ent 83(6): 2462-2468.

7. Press JW (1992) Comparative penetration efficacy in wheat between weevil parasitoids Anisopteromalus calandrae and Choetospila elegans. J Entomol Sci 27: 154-157.

8. Mahal N, Islam W, Parween S, Mondal KAMSH (2005) Effect of Anisopteromalus calandrae in controlling residual populations of Rhizopertha dominica in wheat stores. Int J tropical Insect Sci 25(4): 245-250.

9. Ahmed KN, Pramanik SH, Khatum M (2006) Intraspecific competition between Anisopteromalus calandrae (Howard) and Dinarmus basalis (Rond) on Callosobruchus chinensis. J Biol Sci 14(1): 103-106.

10. Ngamo TSL, Kouninki H, Ladang YD, Ngassoum MB, Mapongmestsem PM, et al. (2007) Potential of Anisopteromalus calandrae (Howard) as biocontrol agent of Callosobruchus maculatus. African J Agric Res 2(4): 168-172.

11. Ahmed KN (1991) Ecology of Anisopteromalus calandrae (Howard), a parasite of stored grain pests. Thesis, Dhaka University, pp: 256.

12. Aslam M, Shaheen FA, Ayyaz A (2006) Management of Callosobruchus chinensis L. in stored chickpea through interspecific and intraspecific predation by ants. World J Agric Sci 2(1): 85-89.

13. Rahman MM, Islam W, Ahmed KN (2009) Functional response of the predator Xylocoris flavipes to three stored product insect pests. Int J Agric Biol 11: 316320.

14. Anonymous (2010) Annual report (2009-10) AICRP on Biological Control of Crop Pests and Weeds, NBAII, Banglore, pp: 220-222.

15. Pereira J, Wohlgemuth R (1982) Neem (Azadirachta indica A.Juss) of West African origin as a protectant of stored maize. J Applied Ent 94(15): 208-214.

16. Doharey RB, Katiyar RN, Singh KM (1990) Ecotoxicological studies on pulse beetles infesting green gram. Bull Grain Tech 28(2): 116-119. 


\section{International Journal of Zoology and Animal Biology}

17. Tiwari SN (1994) Efficacy of some plant products as grain protectants against Rhizopertha dominica (F.) (Coleoptera; Bostrichidae). Int J Pest Mngt 40(1): 9497.

18. Koul O (2004) Biological activity of volatile dinpropyl disulfide from seeds of neem, Azadirachta indica (Meliaceae), to two species of stored grain pests, Sitophilus oryzae (L.) and Tribolium castaneum (Herbst). J Econ Ent 97(3): 1142-1147.

19. Jayasekara TK, Stevenson PC, Hall DR, Belmain SR (2005) Effect of volatile constituents from Securidacalonga pedunculata on insect pests of stored grain. J Chemical Ecol 31(2): 303-313.

20. Chaudhari SV (2013) Herbal Control of Stored Grain Pest Bruchus Chinensis Linnaeus (Coleoptera: Bruchidae). Int J Innovative Res \& Development 2(3): 397-402.

21. Yeshaneh GT (2015) Evaluating grain protectant efficacy of some botanicals against maize weevil, Sitophilus zeamais M. World J Agric Res 3(2): 66-69.

22. Batta YA, Safieh DIA (2005) A study of treatment effect with Metarhizium anisopliae and four types of dusts on wheat grain infestation with red flour beetles (Tribolium casteneum Herbs Coleoptera: Tenebrionidae). J Islamic Univ Gaza 13(1): 11-22.

23. Samodra H, Ibrahim Y (2006) Effects of dust formulations of three entomopathogenic fungal isolates against Sitophilus oryzae in rice grain. Jurnal Biosains 17(1): 1-7.

24. Dhuyo AR, Ahmed S (2007) Evaluation of fungus Beauveria bassiana (Bals.) Infectivity to the larger grain borer Prostephanus truncates (Horn.) Pak Entomologist 29(2): 77-81.
25. McGaughey WH (1978) Moth control in stored grain: efficacy of Bacillus thuringiensis on corn and method of evaluation using small bins. J Econ Ent 71(5): 835839.

26. Ahmedani MS, Haque MI, Afzal SN, Iqbal U, Naz S (2008) Scope of commercial formulations of Bacillus thuringiensis Berliner as an alternative to methyl bromide against Tribolium castaneum adults. Pak J Bot 40(5): 2149-2156.

27. Hunter DK, Hoffmann DF, Collier SJ (1973) Crossinfection of a nuclear polyhedrosis virus of the almond moth to the Indian meal moth. J Invert Path 22(2): 186-192.

28. Rabindra RJ, Subramaniam TR (1975) Nuclear Polyhedrosis of Plusia peponis F. (Lepidoptera: Noctuidae). Curr Sci 44(17): 634.

29. Athanassiou CG, Palyvos NE, Duarte TK (2008) Insecticidal effect of Steinernema feltiae (Filipjev) against Tribolium confusum du Val and Ephestia kueniella (Zeller) in stored wheat. J Stored Prod Res 44(1): 52-57.

30. Laznik Z, Trdan S (2010) Intraspecific variability of Steinernema feltiae (Filipjev) (Rhabditida: Steinernematidae) as biological control agent of rice weevil (Sitophilus oryzae [L.], Coleoptera, Curculionidae) adults. Acta agric Slovenica 95(1): 5159.

31. Canhilal R (2016) The use of entomopathogens in the controlling of insect pests of stored product. Scientific Papers. Series A. Agronomy 59: 235-240. 